\title{
Effect of Nanoparticles on Mechanical Properties of Cement-Sand Mortar Applications
}

\section{José Salvador Cavazos ${ }^{1}$, Gustavo González ${ }^{1}$, Oxana V. Kharissova ${ }^{2}$, Beatriz Ortega $^{2}$, Laura Peña ${ }^{1}$, Mario Osorio², Mauricio Garza-Castañón'}

\author{
${ }^{1}$ Universidad de Monterrey, Physics and Mathematics Department, Engineering and Technologies Division, San Pedro \\ Garza-García, N.L.,México \\ ${ }^{2}$ Universidad Autónoma de Nuevo León, Facultad de Ciencias Físico-Matemáticas, Pedro de Alba S/N, Ciudad Universitaria, \\ San Nicolás de los Garza, N.L., Mexico \\ Email: mauricio.garzac@udem.edu
}

How to cite this paper: Cavazos, J.S., González, G., Kharissova, O.V., Ortega, B., Peña, L., Osorio, M. and Garza-Castañón, M. (2017) Effect of Nanoparticles on Mechanical Properties of Cement-Sand Mortar Applications. Advances in Chemical Engineering and Science, 7, 270-276.

https://doi.org/10.4236/aces.2017.73020

Received: April 27, 2017

Accepted: July 2, 2017

Published: July 5, 2017

Copyright (C) 2017 by authors and Scientific Research Publishing Inc. This work is licensed under the Creative Commons Attribution International License (CC BY 4.0).

http://creativecommons.org/licenses/by/4.0/

\begin{abstract}
Cement-sand mortar is a construction material widely used; tile adhesive is one of the main applications where the compressive strength is the key performance metric. Nanoparticles like MWCNTs and HNTs are currently being used to improve the mechanical performance of the cement mortar due to their properties. The cost of MWCNTs has limited their application in the construction industry. This study focuses on the effect of two different concentrations of MWCNTs and HNTs in cement mortar; HNTs are proposed in this study to compare performance and cost overall benefits. A common problem with MWCNTs is agglomeration; to achieve a proper dispersion an ultrasonic processor was utilized. Mechanical properties of a cement mortar modified with nanoparticles were investigated with compression and bending tests on specimens performed at the age of 7 days. Results showed that concentrations of $0.1 \%$ of MWCNTs increase in compression strength by $56 \%$ and concentrations of $0.1 \%$ of HNTs performance increased by $31 \%$, both compared to plain cement mortar.
\end{abstract}

\section{Keywords}

Mechanical Properties, Compressive Strength, Cement, Cement Manufacture

\section{Introduction}

Cement-sand mortars are used in many applications in the construction industry such as tiles adhesive, interior and exterior coatings, texture, and leveling.

Mortars in tile adhesive applications have high compression strength; to improve mortar mechanical properties several solutions have been proposed in micro 
and macro fibers like Dramix ${ }^{\circledR}$ fibers and glass fibers. In nanoscale, solutions have been used mainly in tubular form like Multi-wall Carbon nanotubes and Halloysite nanotubes, also in the form of flakes like Graphene [1].

In actuality, MWCNTs usage as engineering reinforcement is expanding due to their mechanical properties. MWCNTs have a Young modulus ranging from 270 to $950 \mathrm{GPa}$ and a tensile strength ranging from 11 to $63 \mathrm{GPA}$ [2], making this an ideal reinforcement for cement mortar.

As an alternative for MWCNTs, HNTs are proposed base on mechanical properties, lower cost and present no health risk compared to CNTs. HNTs have a Young modulus ranging from 1 to $1000 \mathrm{GPa}$ and a tensile strength ranging from 0.03 to $4.0 \mathrm{GPa}$ [3].

Studies of MWCNTs on cement mortar reported an improvement in mechanical properties; MWCNT reported in [4] showed 15\% improvement in compression strength and $36 \%$ in tensile strength at concentrations of $0.5 \%$. HNTs reported in [5] showed an improvement in compressive strength of $24 \%$ at concentrations of $3 \%$

To measure the improvement in mechanical properties a mix design was proposed. It consists of a base formula without any nanoparticle addition and two samples with two concentrations of MWCNTs and HNTs. Mechanical properties of a cement mortar modified with nanoparticles were evaluated with compression and bending tests at 7 days; three specimens were performed for each concentration.

\section{Materials}

Cement mortar specimens were prepared using: Portland Cement CPO 30 RB, sand, water and chemical additives.

MWCNTs-Ni were provided by Dr. Oxana Vasilievna Kharissova and Dr. Beatriz Ortega Garcia from UANL. HNTs were provided by Dr. Laura Peña Paras from UDEM, physical properties for both nanoparticles shown in Table 1.

For an appropriate dispersion, a super plasticizer Sika Viscocrete $7300 \mathrm{HE}$ and a $500 \mathrm{~W}$ and $20 \mathrm{KHZ}$ Cole-Parmer Tip Ultrasonic processor were used.

\section{Dispersion of Nanoparticles}

A common problem with MWCNTs is agglomerations, nanoparticles present a high ratio of surface area/volume coupled with a relatively high Van der Waals energy. To avoid this problem was proposed the first sample of MWCNTs was dissolved in $100 \mathrm{gr}$ of water and $2.45 \mathrm{gr}$ of super plasticizer, and then it was so-

Table 1. Physical properties of nanoparticles.

\begin{tabular}{ccc}
\hline & MWCNT-Ni & HNTs \\
\hline Diameter (nm) & $50-80$ & $30-70$ \\
Length (microns) & $10-20$ & $1-3$ \\
Appearance/Form & Black/Powder & White/Powder \\
\hline
\end{tabular}




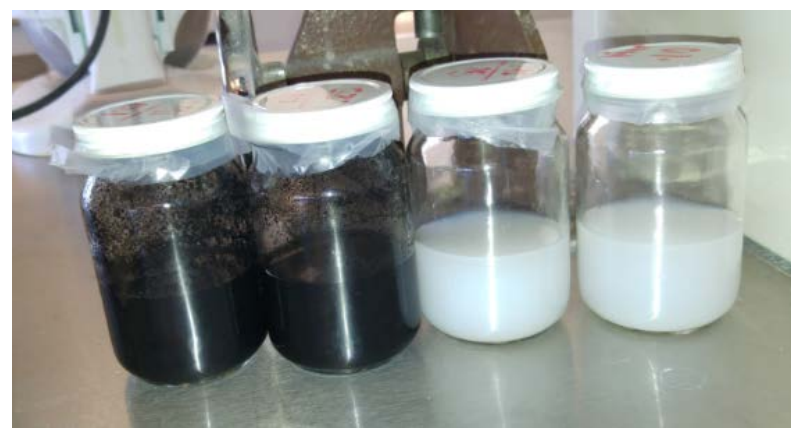

Figure 1. MWCNTs and HNTs sonicated dispersions.

nicated for intervals of 5 minutes, with the ultrasonic processor using a power of $100 \mathrm{~W}$ at $20 \mathrm{KHz}$.

Samples were taken every 5 minutes and observed under an optical microscope at $20 \times$ zoom and observed looking for agglomerations of MWCNTs, continued this process until a similar manner as mentioned dispersion in [6], was determined a time of 30 minutes the ideal, same time used for dispersion is mentioned in [7]. On this basis specimens with two concentrations of MWCNTs and HNTs were sonicated as shown in Figure 1.

\section{Mixing and Specimens Preparation}

The base formula comprises Portland white cement CPO $30 \mathrm{RB}$, sand, and chemical additives. For the preparation of the specimens shown in Table 2, were added in a planetary mixer first water, then the powder mortar, in the case of plain cement mortar. For mixtures with nanoparticles water is added first, then the solution of water + SP and nanoparticles, at last, dust mortar is added as shown in Figure 2. The mixing procedure is according to NMX-C-420, in all mixtures, $26 \%$ water is retained powder mortar. After the mixing is allowed to stand for 10 minutes to remove the air to each mixture. Mix density is reviewed in a bronze glass with a specific volume, the glass is according to ASTMC185 for each formula shown in Table 3. Later proceed to prepare the specimens in the molds for mechanical testing as shown in Figure 2. Specimens cured in a room controlled conditions for 7 days at $45 \%$ relative humidity and a temperature of $23^{\circ} \mathrm{C}$ according to NMX-C- 420 .

\section{Mechanical Testing Equipment}

The scope of this article had the purpose of investigating the mechanical properties of a cement mortar modified with nanoparticles such as compression and bending tests. Specimens were removed from metal molds at 72 hours and then tested at the age of 7 days. The equipment used for testing is a machine by company Controls Dual $15 \mathrm{KN}$ for bending $300 \mathrm{KN}$ compression. Automatic digital model 65-L27D1x, shown on Figure 3 is equipped with two load cells to measure forces with high precision The machine has 2 devices, the first consists of a fixture for standard bending for beams $4 \times 4 \times 16 \mathrm{~cm}$ mortar dimensions according to EN 196-1 the second it is for testing standard compression 
Table 2. Mixture proportions.

\begin{tabular}{|c|c|c|c|c|c|c|c|}
\hline \multirow[b]{2}{*}{ Mixture } & \multirow[b]{2}{*}{ Code of mixture } & \multicolumn{6}{|c|}{ Mixture portions of mortar (grams) } \\
\hline & & $\begin{array}{c}\text { White portland } \\
\text { cement CPO } 30 \mathrm{RB}\end{array}$ & $\begin{array}{l}\text { Sand }+ \text { Chemical } \\
\text { additives }\end{array}$ & Superplasticizer & $\begin{array}{c}\text { MWCNTs } \\
\mathrm{Ni}\end{array}$ & $\begin{array}{l}\text { HNTs } \\
\mathrm{Ni}\end{array}$ & Water \\
\hline 0 & Control formula & 611.4 & 1888.6 & 0 & 0 & 0 & 650 \\
\hline 1 & Cement mortar with $0.10 \% \mathrm{MWCNT} \mathrm{Ni}$ & 611.4 & 1888.6 & 2.45 & 0.6114 & 0 & 650 \\
\hline 2 & Cement mortar with $0.25 \% \mathrm{MWCNT} \mathrm{Ni}$ & 611.4 & 1888.6 & 2.45 & 1.5285 & 0 & 650 \\
\hline 3 & Cement mortar with $0.10 \%$ HNTs & 611.4 & 1888.6 & 2.45 & & 0.6114 & 650 \\
\hline 4 & Cement mortar with $0.25 \%$ HNTs & 611.4 & 1888.6 & 2.45 & & 1.5285 & 650 \\
\hline
\end{tabular}

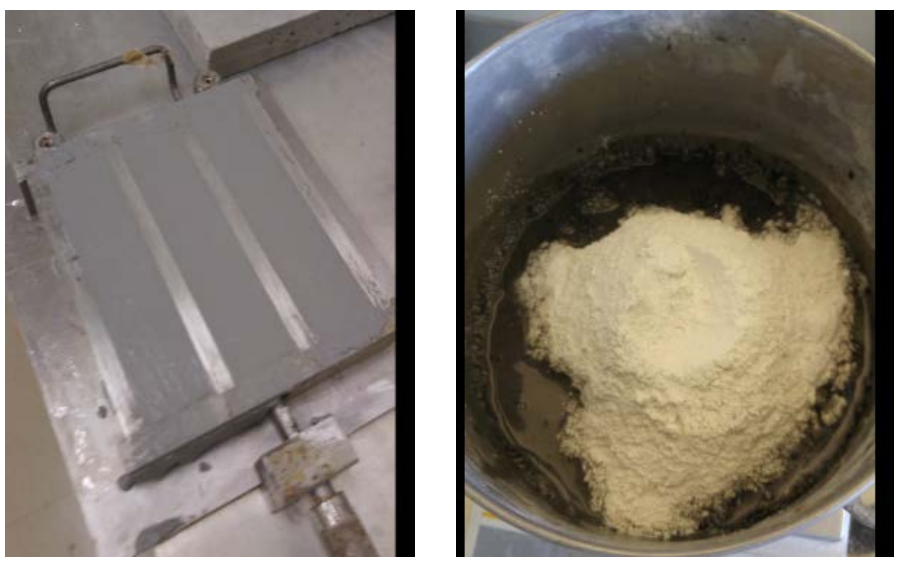

Figure 2. Mixture and specimen preparation.

Table 3. Densities of cement mortar paste.

\begin{tabular}{ccc}
\hline Mixture & Code of mixture & Density gr/cc \\
\hline 0 & Control formula & 1.54 \\
1 & Cement mortar with 0.10\% MWCNTs Ni & 1.46 \\
2 & Cement mortar with 0.25\% MWCNTs Ni & 1.47 \\
3 & Cement mortar with 0.10\% HNTs & 1.48 \\
4 & Cement mortar with 0.25\% HNTs & 1.48 \\
\hline
\end{tabular}
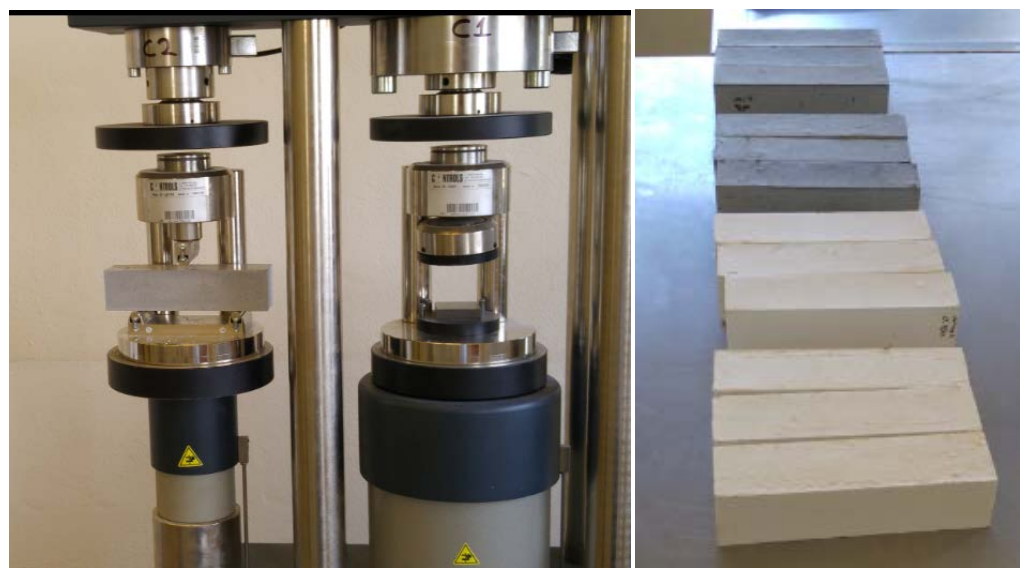

Figure 3. Bending/Compression equipment and specimens. 
Table 4. Mechanical properties at 7 days.

\begin{tabular}{cccc}
\hline \multirow{2}{*}{ Mixture } & Code of mixture & \multicolumn{2}{c}{ Mechanical properties } \\
\cline { 3 - 4 } & Control formula ( Plain cement mortar) & $\begin{array}{c}\text { Compressive } \\
\text { strength } \mathbf{~ k g} / \mathrm{cm}^{2}\end{array}$ & $\begin{array}{c}\text { Flexural } \\
\text { strength } \mathbf{~ k g} / \mathrm{cm}^{2}\end{array}$ \\
\hline 0 & 44.5 & 15.3 \\
1 & Cement mortar with 0.10\% MWCNTs Ni & 69.1 & 16.0 \\
2 & Cement mortar with 0.25\% MWCNTs Ni & 60.4 & 13.4 \\
3 & Cement mortar with 0.10\% HNTs & 57.8 & 15.5 \\
4 & Cement mortar with 0.25\% HNTs & 56.5 & 15.8 \\
\hline
\end{tabular}

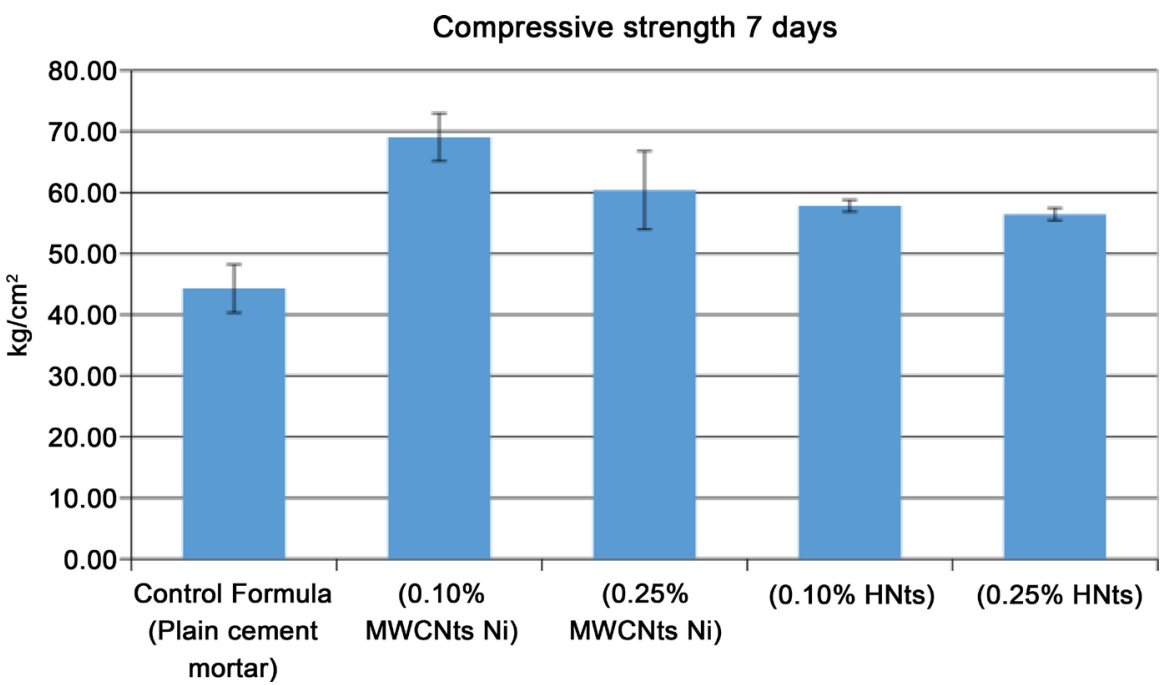

Figure 4. A Chart of compressive strength of specimens at 7 days.

according to EN 196-1, bending previously broken.

\section{Results}

Bending tests and conducted over an area of mortar $640 \mathrm{~mm}^{2}$ at a loading rate of $15 \mathrm{~kg} / \mathrm{s}$ using the bending device, for compression test contact area of $1600 \mathrm{~mm}^{2}$ is used, and a load speed $15 \mathrm{~kg} / \mathrm{s}$, results shown in Table 4 and Charts of Compressive and Flexural strength shown in Figure 4 and Figure 5.

\section{Discussion of Results}

- Sample MWCNTs mortar with $0.10 \%$ on cement mortar, exhibits an increase in the mechanical properties of compression at the age of 7 days of $56 \%$ compared with the control formula, in terms of flexion, there is an improvement of $4 \%$ with respect to control formula.

- Sample MWCNTs mortar with $0.25 \%$ on cement mortar, showed an increase in compressive strength of $36 \%$ at the age of 7 days with relation to the control formula, but a decrease of $12 \%$ in flexural strength at the age of 7 days.

- Sample mortar with $0.10 \%$ HNTs on cement, exhibits a $31 \%$ increase in compressive strength at the age of 7 days, regarding flexural strength at the 


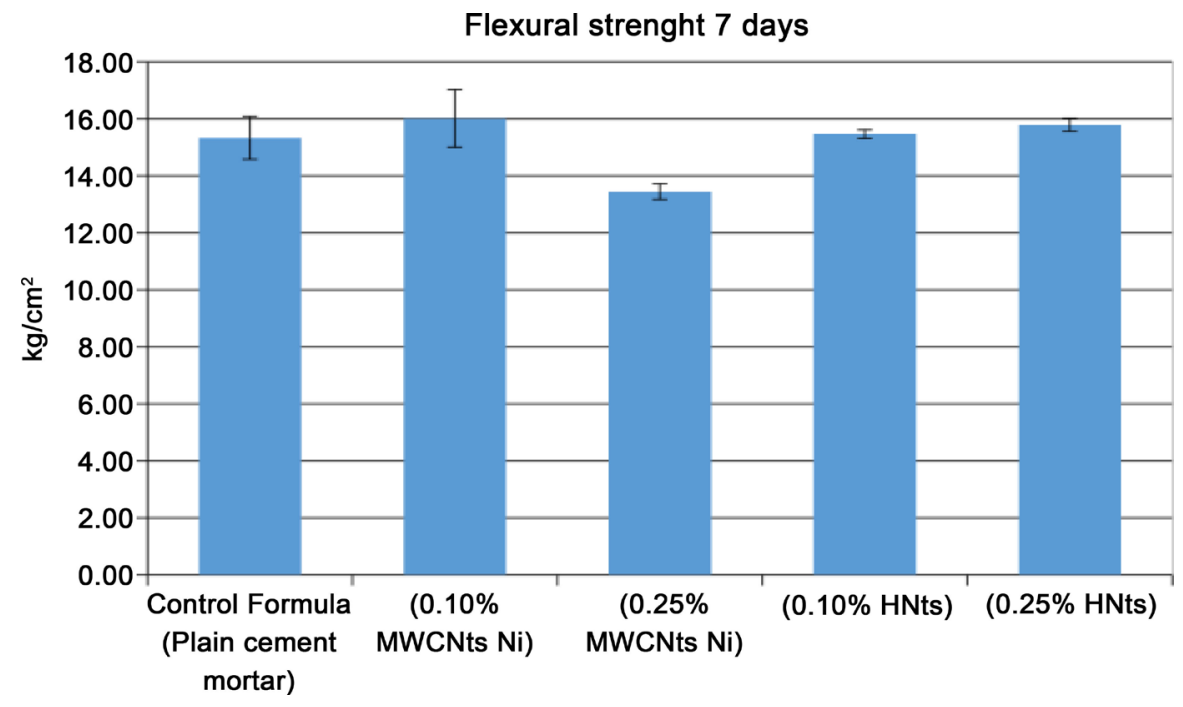

Figure 5. A Chart of flexural strength of specimens at 7 days.

age of 7 days, there was a small improvement of $0.8 \%$ compared with control formula.

- Sample with $0.25 \%$ HNTs mortar on cement, showed a $28 \%$ increase in compressive strength at the age of 7 days and an increase of 3\% in terms of flexion at the age of 7 days.

\section{Conclusions}

Based on the results obtained, we can determine that the lower the concentration of nanoparticles was in cement mortar, the better performance in mechanical properties was achieved. According to the observed standard deviation, in HNTs it was more reduced than with MWCNTs and plain cement mortar; this was due to a better dispersion within the cement matrix.

The impact on the cost as a reference was from Sigma-Aldrich [8]; HNTs cost $\$ 59.10$ USD/100g or $\$ 0.59$ USD/g. and for MWCNTs $\$ 116$ USD/gram.

The $0.1 \%$ specimens of HNTs gave an improvement in compressive strength $16 \%$ lower than MWCNTs with same concentration, but it was noticed that the cost in the industry played an important role in decision-making. An evaluation based on the cost/performance ratio showed that HNTs were a better overall solution for cement mortar performance increase.

Studies are needed in order to review the properties at the age of 28 days and also to evaluate lower concentrations to find the optimal minimum for HNTs.

\section{References}

[1] Horszczaruk, E., Mijowska, E., Kalenczuk, R. J., Aleksandrzak, M. and Mijowska, S. (2015) Nanocomposite of Cement/Graphene Oxide-Impact on Hydration Kinetics and Young's Modulus. Construction and Building Materials, 78, 234-242. https://doi.org/10.1016/j.conbuildmat.2014.12.009

[2] Yu, M., Lourie, O., Dyer, M., Moloni, K., Kelly, T. and Ruoff, R. (2000) Strength and Breaking Mechanism of Multiwalled Carbon Nanotubes under Tensile Load [Abstract]. Science, 287, 637-640. https://doi.org/10.1126/science.287.5453.637 
[3] Yuan, P., Thill, A. and Bergaya, F. Nanosized Tubular Clay Minerals: Halloysite and Imogolite. Elsevier, Amsterdam, Netherlands.

[4] Kumar, S., Kolay, P., Malla, S. and Mishra, S. (2015) Effect of Multiwalled Carbon Nanotube in Cement Composite on Mechanical Strength and Freeze-Thaw Susceptibility. Advances in Civil Engineering Materials, 4, 257-274.

https://doi.org/10.1520/ACEM20150006

[5] Farzadnia, N., Ali, A. A., Demirboga, R. and Anwar, M. P. (2013) Effect of Halloysite Nanoclay on Mechanical Properties, Thermal Behavior and Microstructure of Cement Mortars. Cement and Concrete Research, 48, 97-104. https://doi.org/10.1016/j.cemconres.2013.03.005

[6] Al-Rub, R., Ashour, A. and Tyson, B. (2012) On the Aspect Ratio Effect of Multi-Walled Carbon Nanotube Reinforcements on the Mechanical Properties of Cementitious Nanocomposites. Construction and Building Materials, 35, 647-655. https://doi.org/10.1016/j.conbuildmat.2012.04.086

[7] Caneba, G., Dutta, C., Agrawal, V. and Rao, M. (2010) Novel Ultrasonic Dispersion of Carbon Nanotubes. Journal of Minerals and Materials Characterization and Engineering, 9, 165-181. https://doi.org/10.4236/jmmce.2010.93015

[8] Retrieved July 28, 2016, from http://www.sigmaaldrich.com/united-states.html

Submit or recommend next manuscript to SCIRP and we will provide best service for you:

Accepting pre-submission inquiries through Email, Facebook, LinkedIn, Twitter, etc. A wide selection of journals (inclusive of 9 subjects, more than 200 journals)

Providing 24-hour high-quality service

User-friendly online submission system

Fair and swift peer-review system

Efficient typesetting and proofreading procedure

Display of the result of downloads and visits, as well as the number of cited articles

Maximum dissemination of your research work

Submit your manuscript at: http://papersubmission.scirp.org/

Or contact aces@scirp.org 